Бојан М. Ђорђевић

Универзитет у Београду

Филолошки факултет
930.85(497.11)"1916/1918"

https://doi.org/10.18485/ai_lik.2018.4.5.2

оригинални научни рад

\title{
ЧИЈА СЕ РУКА МАШИЛА НЕПРИЈАТЕЉСКЕ БРАВЕ: О „ИЗДАЈИ“ ИНТЕЛЕКТУАЛАЦА У ПРВОМ СВЕТСКОМ РАТУ
}

У раду се говори о оптужбама против српских интелектуалаца који су у току Првог светског рата остали у окупираној Србији. Они су, у штампи и јавности, у првим годинама после ослобођења оптуживани за кукавичлук, колаборацију и издају. Међу њима били су и највиђенији српски књижевници, попут Исидоре Секулић, Боре Станковића и Симе Пандуровића. Иако су ови књижевници писали за окупаторску штампу, а и на други начин узели учешћа у јавном животу, у раду се показује да њихово деловање није имало елементе колаборације и да је хајка на њих углавном имала личне мотиве.

Кључне речи: Први светски рат, окупација, колаборација, издаја, новине, културни живот.

\section{„Ноћни чувари српског народа и његове имовине“}

Када се Симеон Газда припремао за парницу пред српским судом због колаборације са аустроугарским окупационим властима ${ }^{2}$ (јер беше, у времену и простору Пекићеве нарације, члан Општинског одбора у Београду - који је, заиста, и у реалном времену и простору постојао од почетка тзв. Велике окупације, 28. новембра 1915. па до ослобођења 1. новембра 1918. године), онда је он искусио оно што су и многи други у реалности која је владала Србијом и тзв.

nalesko1965@gmail.com

Borislav Pekić, Zlatno runo VI, Laguna, Beograd 2013, 326.

2 Б. Пекић, нав. дело, 313-367. 
„београдском чаршијом“ у првих неколико година после свршетка Великог рата. Иначе несклоно оним људима - посебно војним обвезницима, интелектуалцима, трговцима и политичарима - који се нису повукли са војском и Владом преко Албаније, србијанско јавно мнење није имало много милости, поготово према онима које је огласило колаборантима, кукавицама и - у најгорем случају - издајницима. Тај глас јавности предочава и Симеон Газда, одмах имајући и спреман одговор:

Сви што смо из нужде или од своје воље у Београду остали поштујемо ваше жртве и муке, али болан дојам имамо да ви наше не само не поштујете, нити признајете, већ их не разумете. Држите да сте једино ви гладовали и зебли, а овде се гладовало и зебло још више. Држите да сте једино ви страдавали и умирали, а страдавало се и мрело овде још горе. Ви сте, најпосле, имали чиме да се браните. Ми, сем памећу, ничим јачим. А сада се тој памети суди. Једином оруђу с помоћу кога нисте по повратку нашли гробље, него сте цвећем дочекани. ${ }^{1}$

Нужност живота у једном за становнике Србије сасвим новом и дотад неискушаном стању окупације (јер, после успоставе Србије као вазалне кнежевине, 1815. године, та модерна држава никада, за пун век, није била под туђинском влашћу; генерације у њој стасале нису имале искуство робовања, осим по причама својих дедова и прадедова о ропству под Турцима), подразумевала је и стављање на пробу тзв. етичког императива. Стање окупације и терора схватало се и међу интелектуалцима као тешка несрећа на коју се треба навићи и прилагодити јој се. Једни су то радили из страха за себе или своје рођаке које су окупатори интернирали, други због голе егзистенције, а трећи - попут Пекићевог јунака Симеона Газде - у уверењу да ће својим деловањем и сарадњом са Војним генералним гувернеманом, тј. аустроугарским властима, умањити несрећу и бар донекле заштитити не само грађане Србије од смрти или интернације, ${ }^{2}$ већ

Б. Пекић, нав. дело, 327.

О таквим побудама сведоче и успомене Стеве Чутурила који је окупацију провео у Трстенику. Он врло детаљно и самокритички описује како се примио положаја председника Одбора за исхрану и заштиту сиротиње и народа. Видети у Чутуриловим рукописним успоменама стр. 101-104. Захваљујемо на уступљеној копији рукописа госпођи Милеви Чутурило. 
и културна добра и институције попут Народне библиотеке или Народног музеја. Нијансе, дакле, тзв. колаборације биле су врло фине и готово невидљиве. Мало их је било међу српским интелектуалцима тога времена - јер о њима је у овом раду реч - који су се у службу окупатору ставили са убеђењем да је пораз српске војске дефинитиван. И ту постоје најмање две варијанте. Неки су у тај пораз веровали у безнађу, у разочараности што су политички прваци са војском избегли и тако жртвовали српско становништво зарад симболичког акта државне независности. ${ }^{3}$ Други су били убеђени германофили, и таквих је заиста било сасвим мало. ${ }^{4}$ Уз то, за разлику од окупације током Другог светског рата, у Србији под аустроугарском управом није радила ниједна културна установа, такође ни Универзитет, постојала је само једна гимназија и једино су радиле - наравно у посебним околностима и под строгом контролом окупатора - основне школе. У таквим условима десила се, заиста, она Хабермасова „структурна промена јавности“, 5 ако ту јавност схватимо као интелектуалну. Иако се нешто слично десило и са онима који су отишли на Крф или у Солун, мора се приметити да су они,

3 „Малодушни су тражили и брзо налазили кривце овој општој несрећи нашој. У кога је језик бржи од памети, просипао је речи ружне и одвратне." Лука Лазаревић, Белешке из окупираног Београда (19151918), Јасен, Београд 2010.

4 Саме аустроугарске власти су, у поверљивим извештајима, истицали оне који су, по њиховом мишљењу, искрено одани сарадњи. Карактеристика о архимандриту Платону добар је пример тога: „Platon hatte die geistliche Akademie in Moskau, absolviert, war niemals den phantastichen Einflüssen der russischen Politik unterworfen. Nach seiner kräftigen Intelligenz und gesunden Logik hatte er es empfunden und stets vertreten, daß es im Interesse Serbiens gelegen ist, eine Politik der Freundschaft mit der Nachbarmonarchie zu führen und daß diese die Nützlichste und Gesündeste für den Staat ist.“ Архив Србије /даље: АC/, Војни генерални гувернеман /даље: ВГГ/ VIII867. Таквих германофила највише је било међу професорима Шесте реалне гимназије коју су у Београду покренули окупатори и у коју је ишло и нешто српских дечака. Оно што је индикативно јесте чињеница да су неки од тих књижевника и филозофа (попут Димитрија Најдановића или Дамњана Ковачевића) били и истакнути колаборационисти током окупације у Другом светском рату!

5 Jürgen Habermas, Strukturwandel der Öffentlichkeit: Untersuchungen zu einer Kategorie der bürgerlichen Gesellschaft, Frankfurt am Mein 1990, 42. 
парадоксално, живели животом који је био много сличнији оном предратном у Србији. Радила су позоришта, гимназије, културна и ђачка друштва и излазило неколико новина. ${ }^{6}$

Мора се такође нагласити да је између ове „две Србије“, једне у избеглиштву а друге под окупацијом, постојао контакт, било преко оглашавања у окупаторским Београдским новинама, било преко вести које су из окупиране земље стизале у Солун, на Крф или у Женеву. Вести су, наравно, стизале и неформалним каналима, и тако се код српских интелектуалаца на Крфу или у Солуну полако формирао став о онима који су остали у Србији. Тај став, у почетку веома амбивалентан и контроверзан, по свршетку рата и повратку у ослобођену земљу биће у многим случајевима крајње заоштрен и формираће атмосферу оптужби која је понекад попримала размере хајке на „колаборанте“ и „издајнике“ међу књижевницима, новинарима, глумцима и редитељима. Та хајка је каткад имала врло сличне поводе (личне, политичке или еснафске) као и она после Другог светског рата, само је била лишена идеолошког предзнака.

\section{„Срби су у нови рат кренули, да себе од издајничке погани пургирају“7}

Генератор хајке која се водила против интелектуалаца оптужених за издају и сарадњу са окупатором била је тадашња штампа. Она је у то време била све само не објективна, независна и одмерена. ${ }^{8}$ У тренуцима када се, тек што је основана, нова држава, Краљевина Срба, Хрвата и Словенаца, нашла у озбиљној кризи, када су на површину испливале све оне несугласице између Двора и Пашића, те између разних странака и

6 Видети: Бојан Ђорђевић, Драгана Грујић, Гордана Ђоковић, Летопис културног живота током Великог рата 1916-1918, Институт за књижевност и уметност, Матица српска, Београд, Нови Сад 2014.

7 Б. Пекић, нав. дело, 321.

8 И Симеон Газда у Златном руну проговара о тадашњој београдској штампи и злоупотреби Закона о штампи, када се под образином заштите слободе јавне речи допуштала (а често од самих политичара и иницирала) најдрскија и најотворенија дифамација политичких противника или личних непријатеља: „Колико је штампа слободна вреди само колико је паметна и поштена. Ако није, слобода јој одмаже, као год и непослушноме детету претерано разумевање.“Б. Пекић, нав. дело, 323. 
покрета - несугласице које су вукле порекло још из Солуна и са Крфа - београдска штампа је наступала с једне стране перфидно и лицемерно, а с друге стране хајкачки и разуларено. И то нису чинили само дневници оних уредника и новинара који су и пре Првог светског рата важили за неморалне, поткупљиве и осветољубиве. Није тај, данас бисмо рекли таблоидни дух, мимоишао ни Политику, која је нарочито у прве три године по ослобођењу, када јој је тон давао Јован Тановић, понекад и предњачила у таквим нападима. Уосталом, ако и није започела хајку, Политика је међу првима означила мете! Доносећи, најпре, вест о сућењу колаборационистима у Паризу - књижевницима и новинарима, и похваливши то што су неки од њих (међу њима и угледно публицистичко и књижевно име Пјер Леонар) стрељани, Политика је прозвала новинара Драгослава Стојановића као сарадника окупаторских Београдских новина. ${ }^{9}$ Само дан касније, као мете су означена много познатија имена. У чланку екстатичног и опасног наслова „Чишћење губе“, овог пута јављајући о суђењу новинарима и књижевницима у Белгији, анонимни аутор јасно је истакао: „Осуђени су белгијски Станковићи, Николајевићи, Исидоре.“10 Коначно, уследио је и позив на суђење „издајницима“, којих, према писању листа, није било мало, већ „на хиљаде“. И са свима њима требало је рашчистити:

Под суд све оне који су служили непријатељу, било непосредно, било посредно - то је оно што данас једнодушно тражи и хоће цела земља... За земљу која је дала милион живота, да би обезбедила своју слободу и будућност, није никаква ни штета ни срамота ако, увек у борби за своје добро, очисти своју средину, па макар се и на хиљаде бројили они који стоје као мрља на њеноме светломе челу. ${ }^{11}$

У маниру који ће бити одлика будућих тоталитарних режима, указивано је даље да ти „поганци“ и даље роваре против нове државе и да „нашем друштву и нашој држави од њих прети једна озбиљна опасност“. Говорило се о

\footnotetext{
11 „Међу нама“, Политика, XVI, 4219 (31. октобар 1919), 3

10 „Чишћење губе“, Политика, XVI, 4220 (1. новембар 1919), 1.

11 „Под суд“, Политика, XVI, 4228 (9. новембар 1919), 1.
} 
„дезертерима, правим и моралним“, о „аустријским сарадницима“, о „конфидентима“ - уопште „неваљалцима који дижу све дрскије главу““12 И питала се Политика: „Ако већ под притиском Савезника редуцирамо списак аустроугарских злочинаца, зашто то чинимо са домаћим изродима?"“13 Стога се, иако из пера једног од оних који су сматрани издајницима, може прихватити становиште о Политици које, уосталом, није било у то време ни ретко ни једино:

Ниједан наш лист, после Ослобођења, није с толико језуитизма почео да фаворизира лаж, као „Политика“. Прећуткујући све кобне политичке погрешке, па чак и злочине почињене у нашој новој држави, и немајући интереса да изусти макар једну реч противу оних који су јаки према њој, „Политика“ је стала да се рекламира и да патриотише на рачун оних, за које је сматрала да су без заштите. ${ }^{14}$

Наравно да ни друга штампа није била ништа блажа, и да је модулирала јавно мнење у правцу осуде и презира према тзв. издајницима. Почело је то, заправо, још 1918. године, са памфлетом у Вечерним новостима против Јована Цвијића, због његове тобожње издаје националних интереса у спору Србије и Бугарске око Македоније. Цвијићево научно поштење и непристрасност гледани су као подлост и слабост карактера. На вест да би, после оставке Николе Пашића, председник Владе могао бити, као неутрална личност, Јован Цвијић, уследио је напад на ову „тимидну личност која се само поводи за струјањима и која нема способности да води. “Али, поред способности, нема ни части. Jер:

Господин Цвијић има један грех на души који му српски народ, а нарочито српска војска, нису могли ни опростити, ни заборавити. То је позната његова брошура о Маћедонији, за време балканскога рата, коју је он по своме политичкоме опортунизму написао, али која је изазвала силно негодовање у целом народу, да је морала бити повучена. ${ }^{15}$

12 „Aфера 'Beogradskih novina“", Политика, XVI, 4255 (6. децембар 1919), 3.

13 „Веселите се, зликовци“, Политика, XVII, 4421 (14. август 1920), 3.

14 Божа С. Николајевић, Наличје „Политике“, Београд 1920 /без пагинације/.

15 „Наивна комбинација“, Вечерне новости, XXI, 44 (8. децембар 1918), 1. 
Иако, дакле, није спадао у оне интелектуалце који су били под оптужбом за колаборацију (уосталом, био је током рата изван земље), Цвијић је, на фону ове оптужбе, имао да претрпи читав низ напада, баш као и други интелектуалци. При томе уопште није узимана у обзир чињеница да су аустроугарске власти још 1915. године наложиле Цвијићево хапшење, јер је „отворено испољавао превратничке намере према Аустроугарској“!16 Оптуживан је за крах плебисцита у Корушкој, ${ }^{17}$ те да је „друго издање Ватрослава Јагића“ и „несвестан савезник свих српских непријатеља“. 18

Уосталом, нису боље пролазили ни други Срби који су за време Првог светског рата агитовали за Србију, несебично се стављајући у службу своме народу. Такви су у листу Крсте Цицварића Београдски дневник провлачени кроз блато, у рубрици која се иронично звала „Савремени типови“. Тој судбини није избегао ни један Михаило Пупин, коме ништа није користила сва финансијска и политичка подршка коју је у Америци изборио за свој народ. Уместо тога, говорило се да је срећа што такав човек није у земљи, баратало се са најпрљавијим инсинуацијама о Пупиновом личном животу, уз оптужбе да је „лажни добротвор“ који је новац прикупљао само да би се ослободио пореза, те да су га до избијања рата плаћали Аустријанци да ровари против идеје Велике Србије! ${ }^{19}$

Не мање жесток био је и напад на Николаја Велимировића, који је оптуживан да је шуровао са Пупином и да се у Америци срамотио јашући ноја. Уз отворене увреде (да је „никакав беседник“, да „лупа као пута о лотру“) исказивала се сумња у његово „извикано родољубље“.20

Па ако су овако пролазили они који су се у до краја ангажовали за интересе Србије и Југославије (и који су имали

16 АС, ВГГ ХVII-1407.

17 Божа С. Николајевић, „Наука и политика“, Балкан, VI, 156 (29. октобар 1920), 1.

18 „Један професор: ко је д-р Јован Цвијић“, Балкан, Х, 118 (1. мај 1923), 1.

19 Видети: „Михаило Пупин-Идворски“, Београдски дневник, I, 10 (12. октобар 1919), 2; 11 (13. октобар 1919), 2; 12 (14. октобар 1919), 2.

20 Видети: „Николај Велимировић“, Београдски дневник, I, 44 (21. новембар 1919), 2. 
веома јаке политичке везе), није чудно да су кроз својеврсног „топлог зеца“ морали тим пре проћи они који су остали у окупираној земљи.

\section{„Ко ће сутра да се бори за ову државу кад они који су служили непријатељу и богатили се његовом помоћу осташе некажњени “21}

Хајка на истакнуте књижевнике и публицисте ишла је у два правца. Они су најпре бивали оптуживани као јавни делатници. Најтежа оптужба била је она да су сарађивали у Београдским новинама, листу који је у Београду издавао Војни генерални гувернеман од децембра 1915. до октобра 1918. године. Новине су излазиле у три издања - српскохрватском, немачком и мађарском. Српскохрватско издање штампано је латиницом, вести су доношене ијекавицом, али су књижевни и други прилози из културе српских аутора објављивани екавицом. Београдске новине је у почетку уређивао гроф Јурај Оршић Славетићки, али су прилози из културе стали да се множе када је уређивање преузео хрватски књижевник Милан Огризовић. Под Огризовићевим уредништвом написи у листу, дотад изразито оштри и памфлетистички када се тиче српског народа и његове културе, постали су нешто одмеренији, мада, наравно, и даље у духу аустроугарске политике. Када је Огризовић 10. марта 1917. године преузео уредништво, ${ }^{22}$ успоставио је везе са српским књижевницима и већи број њих успео да приволи на сарадњу. Доминирала су имена тзв. минорних писаца, али је било и угледнијих књижевника. Један од њих био је Божа Николајевић, а други Милорад Петровић Сељанчица. Њихови прилози претежу у Београдским новинама. Ипак, највећи успех Милана Огризовића био је што је на сарадњу приволео Исидору Секулић (краће време) и Бору Станковића (као

21 Крста Цицварић, „Имајте на уму“, Београдски дневник, II, 191 (26. октобар 1920), 1.

22 Одлуку о именовању видети у: АС, ВГГ VIII-1037. Такође и у: Österreichisches Staatsarchiv, Kriegsarchiv, Personalunterlangen zu Offizieren, I-444/1917, f. 18 
редовног сарадника). ${ }^{23}$ Осим тога, у администрацији листа радиле су удовице двојице великих српских књижевника Клара Скерлић (удовица Јована Скерлића) и Христина Тинка Петковић (Дисова удовица). Њих је запослио Огризовић не би ли им омогућио скромне, али редовне приходе. ${ }^{24}$ Дисовој удовици чак је у Београдским новинама објавио три приповетке и платио јој хонорар као и најплаћенијим сарадницима, Милораду Петровићу Сељанчици и Бори Станковићу. ${ }^{25}$

Београдске новине биле су, међутим, омрзнуте у јавности. Сматране су„одвратним листом“, 26 а већ током окупације на писце који су у њима сарађивали гледало се попреко и с нелагодом. По ослобођењу сви они стављени су на стуб срама и сарадња са Београдским новинама узимана им је као велики грех. Како је већ постављен аксиом да су ове новине биле „један гнусан непријатељски лист“, 27 који „није само вређао и клеветао, он је гаменски исмевао, он је пљувао на Србију и на све што је њено, на све чиме се она поносила и мора поносити“28 - то је јасно да су сви сарадници тога листа били проказани као сарадници окупатора. Највећа срамота и видела се у томе што је „тај гадни непријатељски лист био окупио око себе знатан број српских грађана и међу њима је било и људи који су имали угледне положаје у нашој држави. “29 Како се у тадашњем кривичном закону није могао наћи члан који би

23 О Београдским новинама више: Бојан Ђорђевић, „Музе нису ућутале: културни живот Срба током Великог рата у огледалу тадашње штампе“; у: Б. Ђорђевић, Д. Грујић, Г. Ђоковић, нав. дело, 6-10.

24 Клари Скерлић било је забрањено држање приватних часова, иако је она то више пута тражила. Тек јој је крајем септембра 1917. године, на лично Огризовићево инсистирање, одобрено да може држати часове немачког, француског и енглеског језика, али само за групу од три ученика. Одлуку видети у: ВГГ VIII-1512 (21. септембар 1917).

25 О овоме: Бојан Ђорђевић, „Досад непозната књижевница Христина Петковић“, Прилози за кюижевност, језик, историју и болклор, 80, 2014, 83-88.

26 Л. Лазаревић, нав. дело, 79.

27 Крста Цицварић, „Павле Маринковић и његови најновији скандали“, Београдски дневник, I, 6 (7. октобар 1919), 2.

28 Крста Цицварић, „Бора Станковић као сарадник 'Београдских новина'“, Београдски дневник, I, 6 (7. октобар 1919), 1.

29 Исто, 1. 
се односио на ову врсту сарадње, то су се памфлетисти позивали на суд тзв. јавног мнења, на то што се београдско становништво „скандализовало“ због „несрпског рада под окупацијом“ неких од највиђенијих књижевника. То јавно мнење je, према писању тадашње штампе, захтевало да се „изведу пред суд они коју су украли покров са мајке Србије, а то су разне Боре и Исидоре.“"30 Овакви напади били су понекад као у овом случају - и израз сопствене озлојеђености (Крста Цицварић је рат провео у интернацији у Нежидеру), али је опасност лежала у томе што су они кореспондирали са огорчењем грађанства које је тешко страдало у рату и окупацији, и што се кривац за то све мање тражио у аустријској управи (уосталом, сем ретких изузетака, готово нико од Аустријанаца и Мађара који су чинили зла по окупираној Србији није одговарао), а све више међу онима који су били ту, надохват руке. Призивала се, заправо, револуционарна правда, што је јасно наглашено у уводнику другог броја Београдског дневника:

у суђењу преступницима и издајницима боље је веровати и ослонити се на савест поштених људи, који су својим очима видели и преступе и преступнике и који на себи осећају тежину тих недела, него се ослонити на преживеле законске одредбе. ${ }^{31}$

Да би се то постигло, интелектуалци оглашени за сараднике окупатора морали су бити дифамирани не само као јавни делатници, већ и на личном плану. То је други правац којим је ишла хајка на њих. Основна оптужба, наравно, била је она за користољубље, тј. „среброљубље“. Занимљиво је, у ствари, да готово нико од њих није оптуживан да је био колаборант због свог германофилства или из каквих политичких и идеолошких побуда. Настојало се, заправо, да се „оптуженима“ одрекне било какав карактер и да се сведу на грамзиве и кукавичке типове за које се не може наћи оправдање чак ни у њиховом таленту и списатељској вредности:

Зна се да се талентованим људима често гледа кроз прсте; таленат извињава недостатке њихова карактера. Али ако има

30 Крста Цицварић, „Покров са мајке“, Београдски дневник, II, 114 (28. јул 1920), 1.

31 Београдски дневник, I, 2 (2. октобар 1919), 2. 
грешака које једном талентованом човеку можете и морате опростити, има једна коју му никако и никако не можете и не смете опростити: то је служба непријатељу.

Они више „нису наши“! А као такви, као одроди и „ненационални типови“, били су предати на милост и немилост тзв. београдској чаршији која је итекако сеирила над њиховом судбином. Та индигнација најчешће није била искрена, али је служила, између осталог, да сами нападачи и уопште грађани који су, као и ти књижевници, рат провели у окупираној Србији забораве на своје грехе, на своје компромисе и не увек часне поступке, указујући прстом на друге. Добар пример за то представља однос штампе и тзв. јавности према Исидори Секулић, Бори Станковићу и Сими Пандуровићу.

\section{„Жалим што је наша публика тако мало осетљива кад је реч о отклањању клевета“"32}

Напади на Исидору Секулић нису били увек тако жестоки ни директни, али су тим пре били перфиднији и лицемернији. Одвијали су се најпре под привидом књижевне критике. Негативне судове о Исидориној прози критичари су готово по правилу пропраћали наизглед узгредним подсећањем да је за време рата Исидора била у окупираној Србији и да јој је неколико приповедака објављено у Београдским новинама. Истина је, међутим, да су биле објављене само две приче, и то без Исидорине дозволе. Биле су то приче Чежна $a^{33}$ и Носталгија. ${ }^{34}$ Посебно јој је замерано што је ова друга прича објављена у свечаном броју Београдских новина у част рођендана аустроугарског цара Франца Јозефа. Осим тога, ове и још неке приповетке преведене су на немачки и мађарски и појавиле су се у издањима Београдских новина на немачком и мађарском језику. Тако је Душан Милачић, у својој оштрој критици Исидориног приповедачког рада - писаној на ивици личног напада и памфлета - поред тога што је закључио да она

32 „Поводом једне неправде: писмо г-ђе Исидоре Секулић“, Време, III, 511 (23. мај 1923), 2.

33 Beogradske novine, II, 70 (23. april 1916), Uskršnji dodatak.

34 Beogradske novine, II, 185 (18. avgust 1916), Svečani dodatak. 
„има мало приповедачког темперамента“, да „нема снаге и конструктивне моћи“, истакао да је Исидора очигледно „у великој књижевној декаденцији“, додајући при том, као узгред а врло промишљено, да је „декаденција њеног морала потврђена за време окупације. ${ }^{\text {“"35 }}$ На то подсећа и Ратко Парежанин у својој критици Исидориног Ђакона Богородичине иркве, наводећи да у тој књизи, као и у целом Исидорином опусу, „нема уметности“, а да је то зато што је списатељица потпуно издвојена из „духа народа“, као што је - и то је сад она тачка у којој се прелази граница књижевног дискурса - била издвојена и у ратним данима. ${ }^{36}$ Била је Исидора повремено помињана и у Политици, углавном у склопу напада на оне интелектуалце који су перципирани као сарадници окупатора.

Рекло би се да Исидора Секулић због оваквих оптужби није имала проблема у својој служби професорке Друге женске гимназије. ${ }^{37}$ Ипак, да су је такве гласине које су морале ићи и мимо штампе, кроз тзв. београдску чаршију, погађале сведочи то што је и у молби министру просвете за одсуство због слабог здравља истицала свој патриотизам и клела се да није сарађивала ни на који начин са окупаторским властима:

Одувек врло слабо здравље, порушено сада знатно због потпуног недостатка сваке телесне и духовне неге за време окупације. Затим, порушен и други мој ослонац и отпор. ${ }^{38}$ Никада нисам примила аустријску пару ни аустријску службу, никада нисам потписала аустријску признаницу ни заклетву, ниједаред се нисам мачила аустријске браве ни руковала се са аустријском руком. /подвукао Б. Ђ./ Потрошила сам, стога, сву уштеђевину. ${ }^{39}$

35 Д. 3. Милачић, „Из прошлости Исидоре Секулић“, Београдски дневник, I, 17 (21. октобар 1919), 2.

36 Рпн. [Ратко Парежанин], „Уметност у позоришту и књигама“, Београдски дневник, I, 24 (29. октобар 1919), 2.

37 О просветној каријери Исидоре Секулић видети: Бојан Ђорђевић, „Исидора Секулић као професорка Друге женске гимназије у Београду (према архивским изворима)“, Анали Филолошког факултеma, XXVI, 1, 2014, 37-47.

38 Овде Исидора Секулић мисли на смрт свога супруга.

39 Архив Југославије /даље: АЈ/ 66-402-649 (5. фебруар 1919). 
Но, када је, бранећи себе, Божа Николајевић објавио своју брошуру, он је и Исидору Секулић навео као „вредну сарадницу Београдских новина“" ${ }^{40}$ Она преко тога није могла да пређе и написала је деманти. Индикативно је да тај текст није хтела да објави Политика, и он се појавио у тек нешто раније покренутом листу Време. У том тексту Исидора Секулић се позива на повреду части и у нешто ширем облику понавља ставове из своје молбе министру просвете. Тај текст је објављен као писмо директору листа:

Господине Директоре, молим Вас за велику љубазност да у Вашем листу изађу ових неколико редака који долазе да најзад исправе једну неправду коју већ годинама трпим. /подвукао Б. Ђ./

Још за време рата ме је напао био један женевски лист због уступања неких својих белетристичких написа редакцији аустријског листа у Београду. По повратку наше емиграције, ја сам, из скромности, покушала ствар расветлити једино усменим обавештењем. Жалим што је наша публика тако мало осетљива кад је реч о отклањању клевета, те се тако могло десити да ме г. Божа Николајевић, у последњој својој књизи, поново цитира међу сарадницима аустријског листа. Нека ми се дакле не замери што ћу данас, не само јавно, него и мало уздигнутим тоном, констатовати факта.

Потпуно сиромашна, за све време окупације нисам нигде ухватила за аустријску браву, и нигде примила аустријску пару. Далеко од тога да сарађујем у аустријском листу, нисам хтела радити ни оно што се није замерало, и што су радили многи, и скоро сви. Нисам хтела примати сталну месечну помоћ коју су окупаторске власти давале српским државним чиновницима. Нисам хтела примити повремену помоћ српским женама удовицама. Нисам хтела примити повремену помоћ српским књижевницима. Нисам хтела радити у гимназији, отвореној за нашу децу, али плаћаној од аустријских власти. Нисам, дакле, само се по себи разуме, примила ни хонорар из аустријске редакције, који ми је, преко једне књижаре, био понуђен кад је завршена серија мојих написа. Кад је изашла прва моја ствар у аустријском листу, ја сам била дубоко у унутрашњости земље, и нисам знала ни да постоје окупаторске новине. За дозволу употребе и превођења мојих ствари није ме нико никада молио.

40 Божа С. Николајевић, Под Немиима, Графичко предузеће „Просвета“, Београд 1923, 54. 
Господине Директоре, ја сам Вам за предусретљивост врло обавезана. ${ }^{41}$

Већина тврдњи из овог писма Исидоре Секулић несумњиво је тачна. Она заиста, за све време окупације, није примала никакву помоћ од окупатора и није била у било каквој чиновничкој служби, коју чак, за разлику од рецимо њене пријатељице Милице Јанковић, није ни тражила. Апсолутно је тачно и да је у априлу 1916. године, када се први пут у Београдским новинама појавила једна њена приповетка, Исидора Секулић била изван Београда, о чему сведочи и белешка редакције листа уз приповетку Чежюа:

Za vrijeme ovoga rata bila je gdja Sekulićeva opet bolničarka, ali je pred navalom c. i k. trupa sa ostalim bjeguncima otišla u Aleksinac. Gdje se pak sada gospodja nalazi, nije nam poznato.

Готово је сигурно да је нико није ни питао за дозволу да објави њене приповетке, поготово што је тад још уредник Београдских новина био Јурај Оршић Славетићки (са Огризовићем то се променило, па откад је он постао уредник више није било објављено ништа Исидорино).

Но, остаје питање хонорара за објављене приповетке. То je, очигледно, био главни предмет напада штампе и јавности, па му је и Исидора, како се види, поклонила највише пажње. Данас, на основу досад неуочених архивских докумената, можемо да потврдимо Исидорине речи да је редакција Београдских новина достављала хонораре не лично Исидори (очито на њен захтев), већ преко Светислава Цвијановића („преко једне књижаре“, како вели Исидора). Остаје још питање је ли Исидора тај хонорар од Цвијановића преузимала. Судећи по свему - јесте! Јер, међу документима постоји и Цвијановићева потврда (бар у једном случају, после објављивања Носталгије у свечаном броју у част рођендана Франца Јозефа) да је новац исплатио Исидори Секулић! Ако Цвијановић није слагао Јураја Оршића Славетићког и новац задржао за себе, онда се бар у овом случају (и само у овом) Исидорине речи не слажу са чињеницама. ${ }^{42}$

41 „Поводом једне неправде: писмо г-ђе Исидоре Секулић“, Време, III, 511 (23. мај 1923), 2.

42 Видети: Österreichisches Staatsarchiv, Kriegsarchiv, Personalunterlangen zu Offizieren, I-327/1916, f. 141-142. 
Било како било, изгледа да је ово Исидорино писмо постигло циљ. Иако је чаршија још увек брујала о њеном држању под окупацијом, у штампи се више нису појављивали напади на њу.

\section{„Господин Бора Станковић није више наш““3}

Данас се чини да о судбини Боре Станковића током Првог светског рата и окупације, као и о оптужбама против њега после ослобођења, све знамо. Но, неће баш бити тако. Бора Станковић остаје, засигурно, пример најомраженије личности у Београду после Првог светског рата, неосуђен али и нерехабилитован. На његовом примеру види се шта се све замерало онима који су били од имена и угледа, а остали у Србији после повлачења Владе и војске.

И Бора Станковић првенствено је осуђиван због сарадње у Београдским новинама. Тзв. „афера Београдских новина“ морала је да у први план, уз Божу Николајевића, стави и Бору Станковића. За разлику од Исидоре Секулић, он је вољно пристао да се његови старији текстови штампају у овом листу. Они су излазили у рубрици „Балкански типови“ и злоупотребљени су да би учврстили став германских читалаца о Србима, али и другим балканским народима, као с једне стране заосталим и примитивним људима које цивилизација није дотакла, а с друге стране о тзв. „племенитим дивљацима““44 Још више он се својим суграђанима замерио оцртавајући њихове карактере, понашање и лоше поступке током окупације у рубрици „Београдске шетње“. Бора Станковић у Београдским новинама објавио је четрдесет

43 Крста Цицварић, „Бора Станковић као сарадник 'Београдских новина“", Београдски дневник, I, 6 (7. октобар 1919), 2.

44 Индикативан је, у том смислу, текст неког анонимног аустријског официра који се затекао у Јужној Србији: „Šta li misle ovi primitivni o nama? Da li nas smatraju kao neke nedostižne veličine, ili kao smiješno izopačenje njihove predstave o čovjeku? Bojim se da ne bude ovo drugo. Mi smo na Orijentu, a orijentalac prezire stranca; muslimani zato što nije iste vjere, a ostali stoga, što im je to opšte svojstvo. Ali neka. Mi ćemo prije naučiti da njih razumijemo - no oni nas! To je njemački običaj.“ „Po Balkanu“, Beogradske novine, II, 94 (18. maj 1916), 2. 
четири приповетке и козерије и по томе иде у ред најагилнијих сарадника. После ослобођења та чињеница одредила је његов живот и утицала не само на његов положај у друштву, већ и на статус у књижевном животу двадесетих година прошлога века. Уз то, Бора Станковић објавио је за време Првог светског рата Нечисту крв у Загребу. Сама та чињеница није била ни оптужујућа, ни за зло узимана, јер су многи српски писци сарађивали у хрватским часописима без обзира на ратно стање. Но, Огризовићев предговор том издању, у коме је писао да је Србија оставила Бору Станковића на цедилу приликом евакуације, а да је он доживео препород доласком Аустријанаца јесте оно што је јавно мнење умногоме окренуло против писца. Он је, тако, у Политикином чланку, постао, попут других који су сарађивали са окупаторима, „аустријски сарадник“ и „неваљалац“, а Политика је његово име редовно штампала са крстом испред, као да је мртав! ${ }^{45}$

Но, остаје да се истражи и друга страна напада на Бору Станковића. Наиме, њему се није замерала само сарадња са Миланом Огризовићем и Београдским новинама, већ и изузетно присан однос са Костом Херманом. Омражен у српској политичкој и културној јавности још од времена анексије Босне и Херцеговине, Херман је својим деловањемуокупираном Београду - за разлику од неких других официра попут Огризовића, Ивана Ковачића и још неких - навукао гнев. А у јавности се још за време окупације створила слика о њему као Станковићевом заштитнику. Слика коју Станковић, у свом поштењу и искрености није намеравао да руши. Напротив, он се тог пријатељства није одрицао, ако је судити по његовим посмртно објављеним списима:

Нека сада сви они којима је Херман учинио, помогао, спасао, а можда и са вешала скинуо, ћуте, либе се његова имена, његова познанства и помоћи, ја не могу да будем неблагодаран и да томе човеку не заблагодарим. Каква је он дела противу Срба, српства, имао док је био у Босни и под Аустријом, нека за њих одговара. Ми, у Србији, за време оних страшних дана, имамо њему много да благодаримо. ${ }^{46}$

45 „Aфера 'Beogradskih novina“", Политика, XVI, 4255 (6. децембар 1919), 3. 46 „Из хартија Борисава Станковића“, Време, VIII, 2173 (5, 7, 8. и 9. јануар 1928), 25. 
Напади на Бору Станковића, међутим, нису били руковођени увек чињеницама. Оптуживан да је радио као испомоћ у Народној библиотеци, Станковић се, да је хтео, могао бранити простом чињеницом да су - иако под аустријском управом - руководиоци културних институција били Срби - Урош Предић, Сима Тројановић, Миливоје Башић, Светозар Зарић, и други. Станковић се, уосталом, на таквим пословима није задржавао јер је увек долазио у конфликт са надређенима, посебно са Иваном Ковачићем. ${ }^{47}$

До данас, међутим, нису разјашњене оптужбе против Боре Станковића за „лично непоштење“ и „кулучарски менталитет“"48 Нико се, заправо, није запитао - полазећи од чињенице да је Бора Станковић жртва неправедног прогона - шта је у позадини оваквих инвектива. Истина је да се Станковић није, својим написима у Београдским новинама и својим јавним деловањем, нимало огрешио о свој народ и културу. Но, поставља се питање да ли је он, који је тврдио и ту му треба веровати - да је списатељску сарадњу прихватио због насушног хлеба и осећања захвалности према Кости Херману и Милану Огризовићу који су га спасли заробљеништва - имао још каквих привилегија. Досад потпуно непознати документи сведоче о томе да је Бора Станковић за време окупације имао великих привилегија од стране аустроугарског Војног генералног гувернемана.

Једна од таквих погодности био је сопствени виноград! Наиме, аустроугарске окупационе власти реквирирале су земљу сељака из околине Београда који су били у затвору или интернацији. Та земља додељена је аустроугарским подофицирима и чиновницима који су службовали у Србији. Међутим, и неки Срби добили су нешто земље. Били су то они за које је Војни генерални гувернеман проценио да су поуздани. Међу њима био је и Бора Станковић. Њему је додељено неколико винограда у Гроцкој, као и у околини Смедерева, са којих је он убирао приход. Притом

47 Бора Станковић, Под окупацијом, Одбор за издавање дела Борисава Станковића, Београд 1929, 41-42.

48 Крста Цицварић, „Бора Станковић као сарадник 'Београдских новина', Београдски дневник, I, 6 (7. октобар 1919), 1-2. 
је имао права да продаје грожђе и вино по повлашћеним дакле вишим - ценама од уобичајених, баш као и аустријски официри. Тако је, како нам сведоче архивски извори, тражио 1918. године (дакле пред сам крај окупације) дозволу да у Београд допреми чак десет тона грожђа:

Carskoj i Kraljevskoj Guberniji Srbije, Beograd

Molim da mi se dozvoli da mogu iz smederevskoga i iz beogradskoga okruga uvesti 10.000 klgr groždja radi lične upotrebe. ${ }^{49}$

Окупационе власти нису биле тако великодушне, али су му ипак одобриле да у Београд унесе тону и по грожђа и да од тога направи хиљау литара вина:

Das Gesuch des Borisav Stanković wurde an die Abteilung 5 des K.u. K. M 66/S mit dem Bemerken uebermittelt, dass die EVZ auf Grund des Gutachtens der Nachrichtenabteilung eine Einkaufsbewilligung fuer $1500 \mathrm{Kg}$ Trauben (1000 Liter Wein) im Grocka befuerwortet. ${ }^{50}$

Оваквествари сигурно нису могледа оставе добарутисак код Београђана. Свима је морало бити познато да Станковић има велике привилегије и ојађено становништво које је једва састављало крај с крајем није могло имати разумевања за Станковићеве послове ове врсте. Тим пре што су на оваквим имањима морали кулучити притворени Београђани који су у калемегданској тврђави чекали да оду у интернацију. ${ }^{51}$ Тако је било и са Станковићевим виноградом. Да би се обрало грожђе крајем августа те 1918. године издвојено је двадесет шест притвореника. На списку је и име Симе Пандуровића, који је управо у то време чекао своју интернацију! ${ }^{12}$

Сви ови елементи стекли су се у једној судбини - судбини књижевника који је настојао да се прометне кроз тешке услове рата и окупације, да прехрани и заштити породицу,

49 AC XVII-1339 (26. август 1918).

50 AC XVII-1339 (30. август 1918). Станковић је грожђе у Београд допремио 7. септембра 1918. године.

51 „Стали су хватати свет на улицама и водити га на кулук... Кулучари су радили о свом хлебу и бесплатно, као Старина Новак проклетој Јерини.“ Л. Лазаревић, нав. дело, 95.

52 Видети: Österreichisches Staatsarchiv, Kriegsarchiv, Operationsabteilung - besetzten Gebieten (Serbien), IV-83/1332. 
али који се притом тешко замерио својим суграђанима. Упркос острашћености штампе и јавности, која је попримала и клеветнички карактер, ${ }^{53}$ Станковићу је сигурно замерано још и много тога личног о чему данас нема никаквих података. За разлику од Исидоре Секулић, он се није бранио (а и питање је да ли би му иједан дневни лист изашао у сусрет и објавио такву одбрану), али је оставио у рукопису своја сведочанства о тешком животу под окупацијом и о људској природи која се ломила пред сваковрсним искушењима.

\section{„Према мени није било обзира ни од стране непријатеља, ни од стране мога народа и моје државе ${ }^{\text {(54 }}$}

Случај Симе Пандуровића специфичан је утолико што се преплео са ратном и послератном судбином другог једног српског књижевника, Боже С. Николајевића. Бранећи се од оптужби за колаборацију, нападала су ова двојица један другог бесомучно, и тако - и нехотице - открили пуно чињеница које говоре не само о њиховом држању у трагично ратно време, већ и о атмосфери која је владала у српским интелектуалним круговима после Првог светског рата.

Чинло се у почетку да ће Сима Пандуровић избећи судбину својих колега по перу који су ратне дане провели у окупираној Србији. Њему је једино могло да се замери што му је у септембру 1918. године у Загребу изашао избор из поезије под називом Оковани слогови, али, као што смо већ установили, није он био ни први ни једини српски књижевник који је објављивао у Хрватској током Првог светског рата. Уосталом, Пандуровић је управо некако у то време, у септембру 1918. године, одведен у интернацију, о чему је, са огорченошћу, јављала и српска штампа у Солуну. ${ }^{55}$

53 „Није ништа радио, а имао је да пије бесплатно пива колико му душа хоће (а он је велики љубитељ пива!).“ Крста Цицварић, „Бора Станковић као сарадник 'Београдских новина'“, Београдски дневник, I, 6 (7. октобар 1919), 1.

54 Сима Пандуровић у молби Министарству просвете 28. августа 1919. године. 55 „Сима Пандуровић интерниран“, Велика Србија, III, 884 (26. септембар/9. октобар 1918), 2. 
Да је он и даље уживао велики углед, сведочи чињеница да је његов повратак из интернације у тек ослобођени Београд забележен у тадашњој штампи. ${ }^{56}$ Већ следеће године добио је намештење у Уметничком одељењу Министарства просвете Краљевине СХC, умногоме захваљујући залагању тадашњег начелника тог одељења, Бранислава Нушића. Поверавани су му и врло важни послвои, па је, рецимо, био специјални изасланик начелника за Сплит и Далмацију, са задатком да поднесе извештај о културним приликама у том крају нове домовине и да ради на утемељењу сплитског Народног позоришта за Далмацију. ${ }^{57}$ Међутим, већ из Пандуровићеве молбе за посао провејава очигледно незадовољство и љутња, и као да се у подтексту наслућује да постоје неке сумње у његово држање под окупацијом:

Нужно је поменути да сам последњих година, за време окупације, упропашћен од стране непријатеља материјално и здравствено; да сам због свога исправнога држања био гоњен, затваран и интерниран, и да ни с погледом на то према мени није било обзира ни од стране непријатеља, ни од стране мога народа и моје државе. ${ }^{\text {“58 }}$

Пандуровићу је, како је време одмицало, све више замерано држање током 1916. године, коју је провео у Ваљеву. Што се он тамо нашао, није чудно, јер је једно време пре рата, од 1907. до 1910. године, радио у Ваљеву као професор Ваљевске гимназије и Приватне више женске школе. ${ }^{59}$ Ту, у Ваљеву, он се примио дужности чиновника аусторугарске Крајскоманде, и

56 „Из Нежидера је допутовао наш познати књижевник, госп. Сима Пандуровић, у повољном здрављу.“ Видети: „Г. Сима Пандуровић“, Вечерне новости, XXI, 13 (6/19. новембар 1918), 2.

57 Видети: Bojan Đorđević, „Teatar u Splitu u doba Desničine mladosti: politika i kultura", Split i Vladan Desnica 1918-1945 - umjetničko stvaralaštvo između kulture i politike: Zbornik radova sa znanstvenog skupa Desničini susreti 2015, FF press, Filozofski fakultet u Zagrebu, Zagreb 2016, 199-201.

58 АJ 66-401-649 (28. август 1919).

59 Видети: Државни календар Кралевине Србије за годину 1907, Београд 1908, 66; 74; Државни календар Кралевине Србије за годину 1908, Београд, 1909, 64; 74; Државни календар Кратевине Србије за годину 1909, Београд 1910, 67; 75; Државни календар Краљевине Србије за годину 1910, Београд 1911, 67; 78. 
то ће бити главни разлог што су у Београду јачали гласови који су упозоравали на његово недостојно држање под окупацијом. Слутећи да иза тих оптужби стоји Божа Николајевић, главни Огризовићев сарадник у Београдским новинама, кога су још теретили и за проневеру новца из војне благајне током расула у јесен 1915. године, и слутећи да Николајевић нападајући друге (Исидору Секулић, Милутина Чекића, Бору Станковића и самог Пандуровића), Пандуровић је оштро иступио против њега у свом листу Прогрес, који је, да апсурд буде већи, уређивао заједно са Божиним братом Душаном Николајевићем (трећи уредник био је Драгиша Васић). У оштро интонираном и беспоштедном тексту, Пандуровић је негирао све Николајевићеве оптужбе и пред јавношћу се бранио непобитним чињеницама о својим хапшењима, и у Ваљеву (где је оптужен да помаже комите) и у Београду, па најзад и својој интернацији у Нежидер. У нади да ће овај чланак бити довољан да спере љагу са себе, закључивао је да „мора доћи време када ће се извршити дефинитиван обрачун између неваљалаца и поштених људи у овој земљи. “60

Међутим, ако је до тада Пандуровића нападао само усмено, Николајевић ће сада то чинити у штампи и јавно. За то ће му служити странице листа Балкан, чији је власник и главни уредник био Светолик Савић, али који су делом финансирали управо браћа Николајевић. Није, стога, чудно што су многи написи у том листу били у служби одбране части и угледа Боже Николајевића, ${ }^{61}$ али и што се он често оглашавао тако што је нападао друге за колаборацију са окупатором. Тако је одмах одговорио и Сими Пандуровићу, фокусирајући се на његов „ваљевски период“' пропраћајући то, међутим, сада и документима, као и сведочењима Пандуровићевих познаника и сарадника. У првом свом тексту донео је доказе да је Пандуровић заиста био чиновник ваљевске Крајскоманде. Доказ је била Пандуровићева молба Окружном заповедништву Војног

60 Сима Пандуровић, „Један морални дегенерик“, Прогрес, I, 35 (23. јун 1920), 1. Због овог текста редакцију је напустио Душан Николајевић.

61 Видети нпр.: „Браћа Николајевићи и Кватерник“, Балкан, VI, 4 (18. март 1920), 3; Светолик Савић, „Правда за све: једно зло нашега друштва“, Балкан, VI, 11 (26. март 1920), 1-2. 
генералног гувернемана за град Ваљево, коју је Николајевић однекуд пронашао и у целини објавио:

Част ми је учтиво замолити царско и кр. Окружно заповедништво, да ме изволи одредити на какву административну дужност у овом подручју, да бих на тај начин обезбедио даљу егзистенцију својој породици и у исто време корисно послужио на датој ми дужности. 14. фебруара 1916. У Ваљеву. Сима Пандуровић. ${ }^{62}$

Идући трагом овог Николајевићевог написа, ради провере тачности његовог навода (пошто није приложио факсимил документа), може се установити да га нема међу документима Војног генералног гувернемана у Архиву Србије, али - у потврду Николајевићеве тврдње а, нажалост, и у потврду да је Пандуровић заиста био службеник у аустроугарској окупаторској управи - тај се документ може наћи у немачком преводу у Ратној архиви у Аустријском државном архиву у Бечу. У списку цивилних чиновника у тадашњој Србији налази се и име Симе Пандуровића и његова молба:

Es ist eine Ehre die Kaizer und Königsbezirkskommando zu bitten, mir in diesem Bereich einige Verwaltungsaufgaben zu vertrauen. Auf diese Weise werde ich die Existenz meiner Familie sichern, und zugleich sinnvoll meine Pflicht erfüllen. ${ }^{63}$

После потврде о аутентичности ове Пандуровићеве молбе, може се са више поверења прихватити други документ који доноси Николајевић, а то је једна Пандуровићева песма! Она је пригодна, а намењена је да се чита у част аустријског школског инспектора М. Шоштарића, који је посетио ваљеску основну школу 23. маја 1916. године. Њу је прочитала једна ученица, а имала је наслов Опрочтај вальевске деце са Господином Dr. М. Шочтарићем, зематьским школским надзорником у Србији, приликом юеговог одласка из Валева, на дан 23-V1916. Писана у лаудативном тону, она, међутим, није

62 Божа С. Николајевић, „Два документа о 'патриотизму' Симе Пандуровића, песимисте у поезији и бившег чиновника аустријске Крајскоманде у Ваљеву а данашњег директора 'Прогреса'“, Балкан, VI, 56 (21. јул 1920), 2.

63 Österreichisches Staatsarchiv, Kriegsarchiv, Personalunterlangen zu Zivilisten, I-205/1916, f. 47. 
толико доказ Пандуровићеве сервилности, колико тешког положаја српске деце и српских школа у првим месецима окупације:

Прим'те ову киту цвећа, Знак љубави наше младе. Нек' вас ово цвеће сећа Наших жеља, наше наде.

Увенуће ово цвеће,

К’о што вене цвеће друго, Али спомен на Вас неће Увенути дуго... дуго...

Наше срце кришом јеца, Ал' с уста нам лети жеља: Нек' сва српска од сад деца Стекну нашег старатеља!

Још једна нам жеља лети Из дубине нашег бића: - Живи дуго, Боже свети, Доброг чику Шоштарића!

Ипак, најтежу оптужбу Николајевић је изнео у следећем тексту, ${ }^{64}$ а то је тврдња да је Сима Пандуровић писао по злу познату Ваљевску резолуцију којом се осуђује краљ Александар и Никола Пашић, у којој се тврди да су они упропастили Србију, позива се грађанство да буде послушно окупационим властима, и која као легитимну узима могућност да Србија после рата буде интегрални део Хабзбуршке монархије! Да би то поткрепио, уредник Балкана Светолик Савић донео је у седам наставака исповест Живка Романовића, ${ }^{65}$ осуђеног због „дела велеиздаје“, који је преминуо у затвору

64 Божа С. Николајевић, „Сими Пандуровићу“, Балкан, VI, 60 (25. јул 1920), 1.

65 „Исповест пок. Живка Романовића, професора и новинара“, Балкан, VI. 56 (21. јул 1920), 2; 57 (22. јул 1920), 2; 58 (23. јул 1920), 2; 59 (24. јул 1920), 2; 60, 25. јул 1920), 2; 61 (26. јул 1920), 2; 62 (27. јул 1920), 2. 
чекајући правоснажност пресуде. Живко Романовић је био у Ваљеву када и Пандуровић и радио је као управитељ основне школе. Може се претпоставити да су он или његова деца (којима је Романовићева исповест и намењена, да се, како је рекао, не би стидели свога оца) и дали Николајевићу наведене документе. Он је посведочио да је Сима Пандуровић присуствовао конференцији која је припремила поменуту резолуцију:

Не желећи да будем сам од интелигенције, ја пошаљем по Симу Пандуровића, и он збиља дође пред сам почетак конференције.

И управо на предлог Симе Пандуровића формиран је Одбор за припрему резолуције, чији је председник био Романовић. У том Одбору био је и Пандуровић. Кључно сведочење Романовића, међутим, јесте оно које казује да су текст резолуције саставили управо он и Пандуровић: „До тог доба ја смо и Сима заједнички модификовали предложену резолуцију.“"66 Пандуровић се, додуше, према Романовићевим речима, испрва нећкао, али је брзо пристао, јер се плашио да га Аустријанци поново не ухапсе под оптужбом да је шуровао са комитама. Сем тога, осећао је да дугује Романовићу, јер је управо овај интервенисао да га пусте из затвора. Романовић је, чак, потврдио да је резолуција „писана Симином руком“!67

Ови Николајевићеви написи, додуше, нису имали много ефекта када је у питању одбрана његове части. Николајевић је и даље презиран и његова књижевна каријера, као и углед јавног радника, били су заувек упрљани. Али, ови написи постигли су ефекат када је у питању Пандуровић. Иако је учествовао у јавном животу, уређивао часопис Мисао и објављивао стихове, морао је још много да истрпи, и требало је да прође неколико година да се ова афера слегне и преда забораву.

66 „Исповест пок. Живка Романовића, професора и новинара“, Балкан, VI. 61 (26. јул 1920), 2.

67 Исто, 2. 


\section{„Наста горе доба за нас који у Србији остадосмо насташе апшења, оговарања, тужбе и опадања горе но под Швабама“68}

Судбина оних интелектуалаца и културних радника који су остали у окупираној Србији од јесени 1915. до јесени 1918. године била је тешка и подложна често неразјашњивим страстима и поривима који су јавност терали да их оговара, прогања и дифамира. Поред већ наведених књижевника и научника, још је велики број оних интелектуалаца који су били изложени јавном линчу. Провлачила су се у тадашњој штампи и имена Трише Кацлеровића, Глише Елезовића, Бранка Лазаревића, Милутина Чекића, Чича-Илије Станојевића, Бошка Токина. Јавност је прала своју савест. Неко је морао да буде жртва. Ретко су се чули гласови оправдања и одбране. Они су, истовремено, били и гласови разума, који су указивали на то да је народ који је остао у поробљеној Србији трпео велике недаће, живео под притиском и у страху, често суочен са одржањем голе егзистенције. Тешко се приклањало разлозима попут оног Светолика Савића:

Као много шта друго, тако се и окупација код нас још увек не схвата ни довољно ни правилно. Свет се навикао да олако прими погрешна и злонамерна мишљења, те су несавесни појединци, који су или добро пролазили под окупацијом или све време рата провели у слободној Швајцарској и Француској, постигли својом срачунатом лармом, да је узајамно оптуживање узело сада код нас невероватне и управо опасне размере. ${ }^{69}$

Једнострано гледање на ствар оптерећивало је духове. Српски народ, чија је интелигенција дала толики допринос велкој идеји ослобођења и уједињења, сада је могао да се осведочи и о лошим странама њеног карактера. Те особине, међутим - данас је то белодано - нису биле такве да би ту интелигенцију увукле у вртлог колаборације и издаје. Међусобна оптуживања и пасквиланстски тон чланака у тадашњој

68 Милан П.Зарић, „Његовом Краљ. Височанству Регенту Александру“, Балкан, VI, 48 (12. јул 1920), 1.

69 Светолик Савић, „Правда за све: једно зло нашега друштва“, Балкан, VI, 11 (26. март 1920), 1. 
помахниталој и необузданој штампи нису, ипак, могли да произведу правне последице. Нико од интелектуалаца није суђен због дела која су им се, у обзорју јавног мнења, стављала на душу. Скрупулозност власти и одмереност у просуђивању нечијих поступака претегли су, на срећу, над личном пизмом и популистичким захтевима за „главама сиромашних књижевника српских. “" гледнијих српских грађана, од суда ослобођен Симеон Газда у Пекићевом Златном руну, ${ }^{71}$ то се, у највећем броју случајева, десило и у реалности. Но, одијум је остајао, и он је у случају неких књижевника (донекле Пандуровића, много више Станковића, а сасвим Боже Николајевића) потрајао и до њихове смрти. Такву судску милост, а и опроштај јавног мнења, међутим, нису могли очекивати они који су под истим оптужбама били прогоњени након Другог светског рата, о чему може сведочити и пример Симе Пандуровића, који је тада изгубио тзв. српску националну част и остао без пензије и било каквих прихода. Матрица је, међутим, била иста - установљена у годинама после трагичне и судбинске епопеје српског народа у Првом светском рату.

\section{Извори и литература}

Архивски извори

Архив Југославије

Фонд Министарства просвете Краљевине Југославије

Архив Србије

Фонд Војног генералног гувернемана

Osterreichischer Staatsarchiv

Kriegsarchiv

Мемоарски извори

Лазаревић, Лука. Белешке из окупираног Београда. Београд: Јасен, 2010.

70 Божа С. Николајевић, Под Немцима, Графичко предузеће „Просвета“, Београд 1923, 54.

71 Б. Пекић, нав. дело, 366. 
Николајевић, Божа С. Наличје „Политике“. Београд, 1920.

Николајевић, Божа С. Под Немцима. Београд: Графичко предузеће „Просвета“, 1923.

Станковић, Борисав. Под окупацијом. Београд: Одбор за издавање дела Борисава Станковића, 1929.

Чутурило, Стево. Успомене/рукопис/.

Периодика

Балкан (Београд).

Београдски дневник (Београд).

Beogradske novine (Beograd).

Политика (Београд).

Велика Србија (Солун).

Вечерне новости (Београд).

Време (Београд).

Прогрес (Београд).

\section{Bojan M. Đorđević}

\section{WHICH HANDS GRAB FOR THE ENEMY LOCK: ABOUT BETRAYAL INTELLECTUALS IN THE FIRST WORLD WAR}

\section{Summary}

The paper deals with charges against Serbian intellectuals who remained in occupied Serbia during the First World War. In the first years after their release, they were accused for cowardice, collaboration and betrayal in the press and public. Among them were the most prominent Serbian writers, such as Isidora Sekulić, Bora Stanković and Sima Pandurović. Although these writers wrote about the occupying press, and in some other way took part in public life, the paper shows that their work did not have collaborative elements and that the mainstream of them had mostly personal motives.

Key words: First World War, occupation, collaboration, betrayal, newspaper, cultural life. 